\author{
Taylor RaeAnne Smith
}

Sorbonne University, France

\title{
EDUCATION POLICY AND CREOLE EDUCATION IN GUADELOUPE: AMBIGUITY FOR EDUCATORS IN EDUCATIONAL MATERIALS AND CONCERN OVER A FRENCH- CREOLE INTERLECT IN THE CLASSROOM
}

Summary. Regional languages in France have historically struggled to find their place in the national linguistic landscape, and French-based Creoles, like those of Guadeloupe and Martinique, are no exception. Despite laws and initiatives like the creation of the Creole CAPES (2002) and the propagation of research like Poth (1997) and Cummins (2009) on the benefits of bilingualism, Creole-language education in French overseas departments, like Guadeloupe, is still stigmatized for a lack of standardization by academic policymakers, despite its attested success in the classroom as a tool for improving students' metalinguistic capacities in French. Using a corpus of official Creolelanguage educational guides, pedagogical guides and one elementary textbook featuring exercises focusing on correction of regional French phrases, along with observations of two elementary Creole-language classes in Guadeloupe, this paper aims to analyze and demonstrate that educators often receive mixed messages on how to teach Creole in bilingual classrooms, and that the language is often perceived as a threat by French academic policymakers to the French abilities of students in Guadeloupe-yet that in practice, elementary students are more likely to struggle with Creole than French.

Keywords: Creole; bilingualism; pedagogy; Guadeloupe; education; sociolinguistics.

\section{Introduction}

Regional languages in France have historically struggled to find their place in the national linguistic landscape. It was only in 1945 that the introduction of regional languages was authorized in some high schools, and more formally in 1951 with the loi Deixonne. Hagège describes the situation prior to 1951 as "[...] a situation of defense of French against dialects and not of the integration of these dialects, seen as the languages of enemies; yet we will often hear words that show that this is not the case 5 ." (Hagège, 27, 2000). Attitudes towards regional languages have thus shifted from a status of inferiority to that at the limit of enemies of the State, which came into conflict with the Republic.

5 "[...] une situation de défense du français contre les dialectes et non pas d'intégration de ces dialectes, vus comme des langues d'ennemis ; alors qu'on entendra souvent des paroles qui montrent bien que ce n'est pas le cas." 
French-based creoles, such as those spoken in the French overseas departments, are no exception. While French-based Creoles are given more and more place in the school system, today France remains one of the only European nations which has not ratified Treaty No.148 ("European Charter for Regional or Minority Languages").

Despite all of this, over the past twenty years, the image of Frenchbased Creoles in national French education in the overseas departments of Guadeloupe and Martinique has moved from that of a hindrance in learning French to that of a cultural asset that is starting to gain more recognition on the linguistic level. New research on bilingualism and language acquisition, such as the work of Poth (1997) and Cummins (2009), has shown the importance of mother tongue education, even when it is part of basilect in a diglossic system. Laws and initiatives in France, such as the loi Peillon (reforming education in France) as well as the creation of the CAPES of Creole (the professional degree from the French Ministry of National Education, Higher Education and Research which sanctions five years of study and is done in conjunction with a Master's degree in order to become a teacher at the middle or high school level) in 2002, have tried to introduce Creole as part of the educational program. This progression has given rise in the last ten years to several Creole textbooks and academic programs.

\section{Creole-language planning in the classroom: standardization, acceptation, and trepidation around a French-Creole interlect}

The issue of Creole in the classroom is further complicated by the question of standardization-academics in the Lesser Antilles regions of Guadeloupe and Martinique claim to have a very advanced level of standardization, especially when looking at standardized exams such as the Creole CAPES. The CAPES exam is subject to internal and external debate from students, teachers, and official reviewers and judges, who feel that the students taking the exam still struggle to use the correct orthographic system (two separate systems existing in Guadeloupe and in Martinique) and to eliminate Gallicisms from their Creole. 
This is illustrated by the 2017 CAPES Jury Report, in which we find the following quote (14):

\begin{abstract}
Finally, it is good to remember that this is a test of language, so the exam copies showing graphic inconsistencies, Francisms, or an interlect are unacceptable [...] The ignorance of the rules is difficult to accept [...] It is regrettable that many candidates mix the two spellings (GEREC 1 and GEREC 2) or do not respect the same rules throughout their writing ${ }^{6}$.
\end{abstract}

The structure of the CAPES Creole itself, modeled on the same exam for English, Spanish, German, or any other living language, represents a claim to have a very advanced level of standardization. This idealization of a language standard mirrors that of French (Prudent, 2005, p. 4) and gives rise to an integration of a language still being standardized to the same educational standards as Spanish, German, English, or even an almost linguistically comparable Haitian Creole. This situation is further complicated by the fact that the Creole orthography has found new life on the Internet, where users write Creole with more or less the same grapho-phonological tools that they write French.

We can additionally note the existence of a French-Creole interlect, or the existence of regional Guadeloupean or Martinican French, in the linguistic landscape of Guadeloupe and Martinique. Lambert-Félix Prudent (1993) posited that the French-Creole interlect has its own role in the linguistic macrosystem, meeting the needs of its speakers as a medium term between Frencha language which, despite its status of prestige, is often privileged in exchanges in everyday life, and Creole-an identity language that punctuates daily discourse, but would rarely be used for long periods of time. French plays an acrolectal role in Guadeloupe and Martinique where most speakers can express themselves in both languages.

In the Lesser Antilles, one could say that the societal acceptance of Creole and the elaboration of a general language corpus have evolved at widely different rates (Kloss, 1969). Yet, a great deal of work has been done to change

\footnotetext{
6 "Enfin, il est bon de rappeler qu'il s'agit d'une épreuve de langue, de ce fait les copies montrant des incohérences graphiques, des francismes, ou une composition en interlecte sont inacceptables [...] La méconnaissance des règles de graphie est difficile à accepter [...] Il est regrettable que de nombreux candidats mélangent les 2 graphies (GEREC 1 et GEREC 2) ou ne respectent pas les mêmes règles tout au long de leur écrit."
} 
the sociolinguistic perceptions of Creole. Educational practices on the Guadeloupean level have become more and more open towards Creole education. Most recently an official educational document called "Modalities of school implementation for bilingual classes at 1st degree in the Academy of

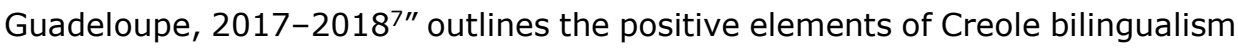
that are often shunned by parents and details the newest plans for bilingual teaching (5):

In short, teachers in the bilingual classes will have to take the following directions: $1 /$ Implement an oral bilingual practice during lessons (explanations, productions, knowledge construction ...) 2/At the French-teaching level: checking and helping to activate a certain number of language skills: arguing, understanding instructions ...

- Integrate a spontaneous variation approach: the starting language can be used as a starting point for learning acquisition of language skills in the standard language. This option would enhance the students' knowledge, make them capable of communicating, and could eventually lead to a change in attitudes and representations towards languages.

- Reach the notion of standard language. Acquiring the memorized forms of standardized French ${ }^{8}$.

Despite being an outline of French-Creole bilingual class teaching goals, the text demonstrates that the notion of the importance of students' acquisition of a "standard French" is impossible to escape and seems to imply that the regional French spoken in Guadeloupe, influenced by Creole, is dangerous for their academic wellbeing. We can perhaps observe a similar attitude in a 2012 study by Bellonie, as he recounts an exchange between an elementary student in Martinique and a teacher, in which the student uses the expression

\footnotetext{
${ }^{7}$ Modalités de mise en œuvre d'école ou classes bilingues au 1er degré dans l'Académie de Guadeloupe

8 "En somme, les enseignants des classes bilingues devront assumer les orientations suivantes : 1 / Mettre en œuvre une pratique bilingue de la conduite orale des leçons (explications, productions, construction du savoir...) 2 / Au niveau de l'approche et de I'enseignement de la langue française : Vérifier et aider à l'activation d'un certain nombre d'habiletés langagière : argumenter, comprendre des consignes... - Intégrer une démarche de la variation spontanée : la langue de départ pouvant servir de point de départ vers l'acquisition de compétences linguistiques dans la langue standard. Cette option permettrait de valoriser les connaissances des élèves, de faire d'eux des « communiquants », et pourrait à terme entraîner un changement d'attitudes et de représentations vis-à-vis des langues. - Parvenir à cette notion de langue standard. Il s'agira d'acquérir les formes de mémorisation de français standard.
} 
prendre sommeil to mean that he fell asleep. While the expression prendre sommeil (literally, to "take sleep") is not considered "standard French," its equivalent does exist in Martinican Creole as pwan sommey. In this instance, the teacher offers a confusing explanation that does little to help the student understand why the phrase is not standard French, and Bellonie (2012) attempts to explain how the teacher should have rectified it.

In such a situation, a relevant remedy would have been to make students reflect on the inter-relation of their production and its inadequacy in relation to the expectations of the school, that is to say, a reflection on what will be evaluated in the Language and Regional Culture -Creole course (the standard form of Creole Martinican pwan somey) or their French class (the standard form of French s'endormir) ${ }^{9}$. (9)

The emphasis here is on the fact that the students' production is inadequate vis-à-vis the expectations of the school and what will be tested during their assessments. Bellonie further argues that the "variation" of regional French (in Martinique) should not be integrated in the school system, as teachers do not yet have a clear enough perception of the norms (Bellonie, 5, 2012).

A similar distinction could be argued in the educational handbook, Annou fè kréyol lékol !, a pedagogical guide for students and teachers:

In kindergarten, he [the teacher] will organize Creole oral production sequences [...] these sequences will reflect on the languages he speaks: Creole, Martinican or regional French and "school" French, of academic success. The PE [instructor] must clarify for the student the rules and standards of the different systems he uses to communicate ${ }^{10}$. (60)

While it is expected that a student should learn about different language registers and which one is appropriate in each social setting and discourse situation, the danger for students may lie in a constant association

\footnotetext{
9 "En pareille situation, une remédiation pertinente aurait été de faire réfléchir l'élève au caractère interlectal de sa production et de son inadéquation aux attentes de l'école, c'est-à-dire une réflexion portant sur ce qui sera évalué en cours de Langue et Culture régionale - créole (la forme standard du créole martiniquais pwan somey) ou en cours de français (la forme standard du français s'endormir). "

10 "À la maternelle, il organisera des séquences de production orale créole [...] ces séquences lui permettront en même temps de réfléchir aux langues qu'il parle : créole, français martiniquais ou régional, français de l'école et de la réussite scolaire. Il s'agira donc pour le PE d'amener l'élève à clarifier et à découvrir les règles et les normes des différents systèmes qu'il utilise pour communiquer (60). "
} 
of "standard" French (difficult to define on purely linguistic characteristics) with regional French or Creole. Despite the number and diversity of Francophones in the world, the ideology of an "oralized" written French of metropolitan France persists.

\section{Methodology and Corpus}

To further the aim of this paper and demonstrate that despite the aforementioned laws and initiatives, Creole-language education in French overseas departments, like Guadeloupe, is still stigmatized for a lack of standardization by academic policymakers, we have chosen a corpus of the official academic documents and pedagogical guides (cited above); an exercise from one elementary textbook sanctioned by the CRDP (Centre régional de documentation pédagogique-Center of regional pedagogical documentation) of Guadeloupe; and elements of observation from two elementary classrooms. The present focus will be on the elementary setting. While elementary criteria rely heavily on distinguishing Creole from French, the high school curriculum makes major jumps in difficulty, and assumes that students will be able to write about and discuss such complex topics as globalization, history, and anthropology, as defined in the Ministry of Education's 2011 foreign language programs. Thus, the fear of students confounding the two languages seems to dissipate and is replaced by an assumption that they will have mastered the languages.

\section{Research limitations}

Due to school policy laws surrounding student privacy, it was not possible to include socioeconomic factors regarding each student's background in the study, nor to collect additional information about the volume and intensity of Creole spoken in the family home. This information may have provided interesting correlations between parents' occupations, the number of hours of Creole spoken at home, and the student's abilities in Creole and in French. The limited sample size of only forty-three students is not large enough to represent all of Guadeloupe and its thirty-two communes, and additional 
studies with a larger sample size is crucial for the advancement of Creolelanguage studies in education. Finally, it is possible that both the students and teachers being observed felt increased pressure due to our presence, and student and teacher responses noted during the observations may not accurately reflect the daily classroom exchanges and linguistic phenomena.

\section{Classroom observations}

A series of classroom observations were carried out in the French overseas department of Guadeloupe in October 2018 in two elementary school classrooms, with excerpts transcribed by the author below. The first class observation took place in Morne-à-l'Eau, situated in the Grande-Terre region of Guadeloupe, in a classroom of twenty students, aged 9-10. The second classroom observation took place in Les Abymes, in a bilingual French-Creole classroom, with twenty-three students aged 9-10. Informed consent was provided by the directors of each school, the teacher, and the pedagogical director, who was also in attendance during observations. During both classes, no direct contact was established with students-while our presence was briefly introduced by the accompanying pedagogical director, teachers and students were instructed to go through a typical lesson.

Students in both groups had the freedom to speak and answer questions in both French and Creole but were encouraged to do so in Creole. The first class centered around a short text in Creole by Maryse Condé from Hugo le terrible (Maryse Condé, 1991), while the second class worked on an exercise to find a synonym, in French and in Creole, for the Creole word kayé. During both classes, the respective teachers spoke almost exclusively in Creole.

Students in Class 1 (Morne-à-L'Eau) seemed excited to be speaking Creole, and class participation was high throughout the class-almost every student raised their hand at some point throughout the lesson. While the teacher admitted in a post-class interview that not having an official Creole textbook was difficult, the chosen text from Hugo le terrible, as a children's book, seemed well-suited to their needs and understood by all of the students. 
Instead of their French being marked by Creole traits, the students' Creole in this class was highly marked by French traits, both phonetically and morphologically. In such instance early in the class, a student reading the excerpt from Hugo le terrible mispronounces nonplis (pronouncing it in French), rather than in Creole, with each letter pronounced. When the instructor asks the students if anyone made any mistakes during their reading, one student points out the other's mistake. The exchange takes place in Creole. In the following examples, the abbreviations FR and CR denote French and Creole respectively. Instances of code-switching will be marked by an asterisk.

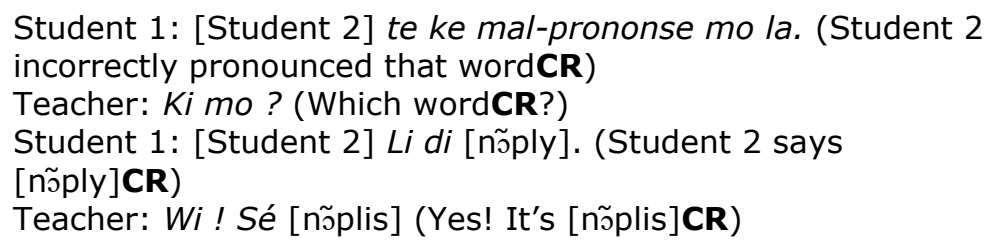

In other instances, the students (and on occasion, the teacher) use various Gallicisms, including partitives and prepositions that typically do not exist in Creole:

Student 1: Sé papa Loran, Rafayèl é Antwan. (It's Laurent, Rafael, and Antoine's dadCR)

Teacher: Pourquoi sé papa la ? Kijan sav sa ? (*WhyFR is it their dad? How do we know? CR)

Student 1: Paske sé des personnes... (Because it'sCR *people...FR)

Student 2: Des moun à Felix-Emmanuel...(FR[plural partitive article] *peopleCR *ofFR Félix-Emmanuel.)

Instead of interphrasal code-switching, we might argue that these young students may not yet have a firm enough grasp of Creole grammar and vocabulary to not draw upon the lexifying language, French, to fill in gaps. While Student 1 uses the word personnes, Student 2 uses the expected Creole moun which then poses no comprehension problems to the rest of the students and seems to be passively understood. The use of the partitive article des before moun seems to be an instance of unfamiliarity with Creole grammar, in which partitive articles do not exist except in the case of agglutinated nouns, 
and not an intentional act of code-switching. The teacher uses the French word for why, pourquoi, but later in the class uses the more expected Creole poukisa.

In another instance, the teacher asks the meaning of the word aristokat, found in the text, denoting in Creole a family of high-social stature.

Student 1: Ils ont pas le même caractère. (They don't have the same characterFR)

Student 2: Ils ont pas le même niveau. (They don't have the same levelFR)

Teacher: Niveau ? Niveau de quoi ? (Level? Level of what?FR)

Student 2: Je sais pas... pa menm fòs (*I don't knowFR *not the same forceCR)

Teacher: Pa menm fòs ? Kijan dè fòs ? (Not the same force?

What kind of forceCR)

Student 2: Vent ? (WindFR)

Teacher: Vent ? Ou palé de yon personne ? Eske aristokat la sé pli beau ? Ki moun est aristokat ? Nan conteks la ?

(*WindFR? ${ }^{*}$ Are you talking about a personCR? Is an

aristocrat more *attractive $\mathbf{F R}$ ? Who $*$ isFR an aristocrat in this context? CR)

Student 3: Sé fanmi Félix-Emmanuel. (The family of FelixEmmanuelCR)

Teacher: Sé fanmi Félix-Emmanuel. Sé moun ki pa menm nivo sosyal. Li plis fòs men pa fòs fort men fòs entelektyèl... sé an keskyon dé nivo sosyal. (Félix-Emmanuel's family. It's people that don't have the same social level. They're stronger but notCR *strongFR strong intellectually...it's a question of social levelCR)

While the student spoke with greater ease in French, the fact that the exchange took place in French made it no more or less difficult for the two students to come to a conclusion about the meaning of the word aristokat. The confusion about wind is likely related to the story centering on the damage that Hurricane Hugo caused in Guadeloupe, the student thus associating force or fòs with a physical force. The teacher's use of the word beau (attractive) is also interesting, as we would expect the Creole form bèl (from the female French belle). While the word bò exists in Creole, it denotes the edge of something (bord in French). Even for the instructor, it seems that French is influencing the Creole vocabulary, rather than Creole influencing French.

Students in Class 2 (Les Abymes) were in a bilingual French/Creole class, which gives them the opportunity to, during any subject, speak French or Creole. In this particular lesson, students were given a short text, in which 
two students get into an argument and schedule to settle their problem in the courtyard after school. Before their meeting, one student kayé or runs away from their fight, and back to his mother's house. Before working on groups to determine both French and Creole synonyms for the word kayé, the teacher went through various contextualizing exercises.

Teacher: Sé sal1. Il faut le lire plusieurs fois pour bien comprendre. Ki moun a fait menm demarch la ? Ki moun font zot demarch? (That's itCR. *You must read it several times to understand it wellFR. $*$ Who CR $*$ didFR $*$ the same processFR?)

Student 4: J'essaie plusieurs mots pour voir si ça marche. (I try several words to see if it worksFR.)

Teacher: Dakò. Es ou pe di menm fraz la sa an krèyol ? Ki moun pe le di ? (OK. Can you say the same sentence in CreoleCR? *Who can sayCR *itFR?)

Student 3: Elle dit que// (She says thatFR//)

Teacher: Attends. Li di ki I ne pe di fraz an krèyol, ou pe di fraz an krèyol? (WaitFR. *She says she CR *can'tFR [negation particle] ${ }^{*}$ say the sentence in Creole, can you say the sentence in CreoleCR?)

Student 3: Elle dit que// (She says thatFR//)

Teacher: Ou pa pale krèyol. (You're not speaking CreoleCR) Student 3: [Student 4] di... elle essaie plusieurs mots et si ça marche pas elle utilise un autre mot. (Student 4 saysCR...*she tries different words and if it doesn't work she uses another wordFR.)

Teacher: Dakò. Ki pe di fraz la an krèyol ? (OK. Can you say the sentence in CreoleCR?

Student 5 : Li di...li di ke si mo... (She saysCR *thatFR...she says *thatFR if the word CR...)

Teacher: Si mo la pa ka mache adan fraz la li utilize mo qui a menm sans... sé sa. Li cheche yon mo, yon lot mo ki té ké sans nan fraz la sa. E si sa ni du sens li gade. Sé sa ? Kijan kriyé mo-differan mo ki ont menm sans la. Nou pe prann mo franse ou mo krèyol sé menm mo la. Wir? (If the word doesn't work in the sentence she uses a word $\mathbf{C R}$ *that hasFR the same meaning... that's it. She's looking for a word, another word that makes sense in this sentence. And if it makes sense, she keeps it. Is that it? What do we call a word-a word that's different but thatCR *hasFR the same meaning. We can take a French word or a Creole word and it's the same word. RightCR?)

${ }^{11}$ Or possibly c'est ça in French. This example illustrates the many utterances that can be classified as both French and Creole, and may serve their own function in the FrenchCreole linguistic micro-system, allowing the speaker to not have to choose between the two languages.

${ }^{12}$ Again, this could be interpreted as the French oui. 
Due to the student's insistence on starting his phrase in French multiple times, it seems apparent that he was aware he was not speaking Creole, but was just struggling to finish his sentence, perhaps due to the difficulty of using a reported discourse structure. Both the teacher and the student employ a variety of Gallicisms, including the relative pronoun ke (que in French) and various forms of avoir (to have) where one would expect the Guadeloupian Creole ni or tini.

At one point, the teacher asks the students what the French definition of kayé is, to which they respond cahier (notebook); indeed, a synonym for the homonym. To dispel confusion, she leads the students in discussing its grammatical category. While a good technique in and of itself, the discussion is further complicated by the fact that the idea of grammatical categories in Creole is a complicated topic, not covered anywhere in the pedagogical material for teachers of Creole. Because no teaching norms have been set in regard to these more difficult topics, and no in-depth textbook exists for both teachers and students, metalinguistic Creole discussion has to be calqued into French terminology:

Student 5: Euh kayé veut dire... un cahier. (Uh kayé meansCR...*a notebookFR)

Teacher: Un cahier. Dakò. Kaye adan nou pe maké, kaye pou lekol la. Es kaye la sa ? (*A notebookFR* OK. A notebook we write in, the notebook for school. Is it that kind of kayeCR?) Student 5: Mwen konprann ke... euh (The way I understand CR...uh)

Teacher : Adan fraz la. "Yo té ba yo randévou dèwò, apré lékòl pou yo té goumé. Mè premyé-la kayé é rantré akaz a manman'y »Wi ? (In the sentence "They planned a meeting after school to fight. But the first one kayé andFR went home to his mom's house." RightCR?)

Student 5: Qu'est-ce que tu as ? (*What do you haveFR?) Teacher: Qu'est-ce que tu as ? C'est-à-dire ? Tu peux expliquer? Qui peut traduire la dernière phrase ? Qui peut expliquer la dernière phrase sans dire le mot? (*What do you have? Meaning? Can you explain? Who can translate the last sentenceFR?)

Student 6 : Il est parti chez sa maman. (*He went to his mom's houseFR.)

Teacher: Il est parti chez sa maman. Est-ce que vous êtes d'accord avec le mot cahier ici ? (*He went to his mom's house. Do you agree with the word notebook hereFR?

Student S: Non. (NoFR.) 
Teacher: Non. Ki natè mo « kayé » la? Ki natè ${ }^{13} a-y$ ? Quelle kategori gramatikal ka mo la sa ? Ki pe di mwen ki kategori gramatikal ? (NoFR.*What's the nature of the word kayé? What is its nature $\mathbf{C R}$ ? ${ }^{*}$ WhichFR grammatical category is this word? Who can tell me what grammatical category it is?) Student 6 : Ki mo é sa ? (Which wordCR?)

Teacher: Le mot kayé dans cette phrase-là, quelle est la catégorie grammaticale ? Es yon non ? Es sé yon adjektif kalikatif ? Es sé yon veb ? Es sé yon pronon ? Es yon determinan? Ki kategori gramatikal a-y ? (*The word kayé in this sentence, what's its grammatical categoryFR? Is it a noun? Is it a qualificative adjective? Is it a verb? Is it a pronoun? Is it a demonstrative pronoun? What's its grammatical categoryCR?)

Student 8: Sé yon non. (It's a nounCR).

Teacher: Sé yon non. Alos [student 7] di ke sé yon nom. Ka di zot ? (It's a noun. So [Student 7] says it's a nounCR)

Student 9: Mwen pa dakò. (I don't agreeCR.)

Teacher: Poukisa? (WhyCR?)

Student 9: Parce que ça commence pas par une majuscule. (*Because it doesn't start with a capital letterFR)

Teacher: Ah dites-moi, quels sont les noms qui commencent par une majuscule ? (*Ah, tell me, which nouns start with a capital letterFR?)

Student 8: Les noms propres. (*proper nounsFR.)

Teacher: Les noms propres. Est-ce que là kayé commence par une majuscule ? Les autres ? Non ? Donc ce n'est pas un nom propre. Euh noms communs, rappelez-moi, comment on reconnaît un nom commun ? (*Proper nouns. Does kayé start with a capital letter? Everyone else? So it's not a proper noun. Uh common nouns, remind me, how do we recognize a common nounFR?)

Student 9 : Un objet, un sentiment. (An object, a feelingFR).

Towards the end of the lesson, after having acted out the scene and finally coming to an understanding of a definition, the teacher asks the students to propose synonyms in both French and Creole, and a variety of expressions, a task facilitated by this Creole exercise.

Thus, in both classes, we see a willingness and desire for students to speak Creole and to expand their vocabulary and understanding; difficulty for both students and teachers to maintain a strictly Creole environment throughout the lesson with no French influence; and a mutual benefit in both French and Creole linguistic practices in the classroom.

${ }^{13}$ Perhaps a Creolization of nature; we might instead accept the créole nati. 


\section{Kréyòl fanm chatengn}

Kreyòl fanm chatengn is a book of French and Creole exercises, written by Sylviane Telchid and published in 2003 by the CRDP of Guadeloupe. It is intended for use in elementary and middle school. The book was published only one year after the first official program for teaching Creole in school was published by the French national education department. In the book's foreword, then National Education Inspector, Moise Sorèze, writes that the then National Education Minister had asked teams from Martinique, Guadeloupe, and Reunion to present teaching programs and materials to the academy for publication and diffusion-yet, it was Sylviane Telchid who took the lead to create a first textbook/exercise book (5). As of today, it is unclear whether the assigned teams mentioned in the preface ever presented their own educational materials.

This textbook has been selected because it was sanctioned by the official CRDP of Guadeloupe (center for pedagogical documentation). While newer textbooks exist, it is still of the only ones listed on the official departmental website, which would suggest it is still being used by teachers. One exercise from a section entitled Pa mélanjé kréyòl épi fwansé kréyòl sé kréyòl, fwansé sé fwansé (Don't mix Creole with French: Creole is Creole, French is French) presents students with regional French phrases, which they then have to rewrite in "standard" French and Guadeloupean Creole.

In one such example, students must change the following sentence in regional French: À quelle heure tu prends sommeil, le soir ? (What time do you go to sleep at night?) into Creole: $A$ ki lè ou ka pwan sonmèy lèswa ? (What time do you go to sleep at night?) and "standard" French: À quelle heure t'endors-tu le soir ? (At what time do you fall asleep at night?). Notice that both the regional French and Creole phrases maintain the aforementioned prendre sommeil (with a different orthography than the above Martinican version) meaning literally to "take sleep." However, in the "standard" French version, this phrase has not only been removed, but the entire syntactical structure has changed into a question by inversion-a trait that, while used in writing, would hardly be used in oral metropolitan French.

In another example, a sentence defined as regional French: C'est pas ça qui s'est passé, tu as mal parlé (That's not what happened, you're speaking 
incorrectly), is given in Creole as Ou mal palé, a pa sa ki pasé (You're speaking incorrectly, that's not what happened) to "standard" French, Tu t'es trompé, les choses ne sont pas passées de la sorte (You were wrong, things didn't go that way). While mal parler is possibly the only true instance of regional French in this utterance, it would be perfectly normal to hear a Metropolitan French speaker use the first one-even more so likely than the final one.

Throughout the textbook, the "corrected" version of regional French phrases use highly formal structures and vocabulary that would sound alien in their oral form, and risk convincing school children in Guadeloupe (or in Martinique) that metropolitan French is akin to speaking a type of oralized written French, which is not the case.

\section{Conclusion}

There is little question that Creole education in Guadeloupe has gained incredible ground in the educational realm in the last ten years, and that it continues to be upheld as an important part of the national patrimony. The continued creation of pedagogical tools and new educational standards points to a positive future for Creole in school. Despite these positive steps, it will likely remain difficult for Creole to find its place without true textbooks, defined by the same norms as for French-language elementary textbooks. Standardization of Creole in education seems to have suffered from a "topdown" approach, in which norms were somewhat established in highereducation in order to put the CAPES in place, while methodological materials for the elementary, middle, and high school classrooms, are difficult to find.

The materials that do exist often suffer from some organizational and pedagogical concerns, and may occasionally, inadvertently contribute to continued feelings of linguistic inferiority. The standards created for the CAPES tend to rely heavily on the idea of "maximal deviance" from French, further complicating things for the newest generation of Guadeloupean Creole speakers. Education policymakers continue to be most preoccupied by the threat of a French-Creole interlect encroaching on standard French and will spend most resources on avoiding this fate. The very norms on which "standard" or "academic" French were founded on are based on written French 
as a model. Pedagogical materials often seem to focus on folkloric elements in order to hinder Creole from entering students daily French.

Despite a fear of a creeping French-Creole interlect entering the classroom, our observations showed that the students in the two classes were perfectly capable of separating French and Creole enunciations, and only seemed to struggle at times when speaking Creole, which tended to include some Gallicisms. Whether or not the difficulty can be attributed to the fact that they occurred during moments of reported discourse, or that they represented gaps in Creole grammatical structure, as opposed to true examples of interphrasal code-switching, is unclear.

Students in both classes highly enjoyed the subject matter, and through Creole, were able to gain insights into a particular historical event (Hurricane Hugo) or additional French and Creole vocabulary (through the kayé exercise); however, when the subject matter turned to grammatical explanations, both the students and the teachers appeared less comfortable with the subject matter, relying on French grammatical models calqued onto Creole. Based on the written pedagogical tools in our corpus, it seems that both students and teachers would benefit from having clearer standards on how students are expected to progress, the specific grammatical and lexical Creole elements that are to be taught, and how, from a psycholinguistic and grammatical perspective they are to be taught to students, beyond general suggestions of a comparative teaching approach.

\section{References}

Académie de la Guadeloupe. (2018, September 6). Modalités de mise en œuvre d'école ou classes bilingues au 1er degré dans l'Académie de Guadeloupe (2017/2018). Retrieved from https://pedagogie.acguadeloupe.fr/sites/default/files/File/bhibade/cla sses_bilingues_cadre_de_mise_en_oeuvre_2017-2018.pdf.

Auroux S. (1994). La révolution technologique de la grammatisation, Liège: Mardaga. 
Bellonie, J.-D. (2012). Une didactique du français adaptée aux situations de créolophonie : le cas de la Martinique. Le français aujourd'hui, 176(1), 113-122. doi:10.3917/Ifa.176.0113.

Bernabé J., (2016). Réflexions sur le statut et les pratiques énonciatives des créoles. In J.-B.P. Durizot (Ed.), Les cahiers créoles du patrimoine de la Caraïbe : pawòl maké asi mès é labitid an péyi karayib (pp.42-47). Chasseneuil Du Poitou: Réseau Canopé.

Blerald M. (2017). Concours de recrutement du second degré : Rapport de jury, CAPES externe, langues régionales. Créole, Ministère de l'Éducation Nationale.

Bolus, M., (2010). The Teaching of Creole in Guadeloupe. In B. Migge I. Léglise and A. Bartens (Eds.), Creoles in Education: An appraisal of current programs and projects (pp. 81-86). Amsterdam: John Benjamins Publishing.

Cummins J., (2009). Fundamental Psycholinguistic and Sociological Principles Underlying Educational Success for Linguistic Minority Students. In T. Skutnabb-Kangas, R. Phillipson, A.K. Mohanty, M. Panda (Eds.), Social Justice Through Multilingual Education (pp. 19-37). Bristol: Multilingual Matters.

Hagège, C., (2000). La place des langues régionales dans l'enseignement précoce des langues. In C., Coyos, J.-B. Coyos (Eds.), Langues et cultures régionales de France: état des lieux, enseignement, politiques (pp. 20-31). Paris: L'Harmattan.

Haugen, E., (1966). Dialect, Language, Nation. American Anthropologist, 68, pp. 922-935. doi:10.1525/aa.1966.68.4.02a00040

Kloss, H., (1969). Research Possibilities on Group Bilingualism: A Report. Centre international de recherches sur le bilinguisme / International Centre for Research on Bilingualism, Université Laval, Québec.

Nazaire, R., Derrien, E., and Prudent, L.-F., (2009). Annou fè krèyol lékol. Fortde-France : CRDP de l'académie de la Martinique.

Poth J., (1997). L'enseignement d'une langue maternelle et d'une langue non maternelle. Centre International de Phonétique Appliquée - Mous Guide pratique Linguapax. Mons: UNESCO.

Prudent, L.-F., (1981). Diglossie et interlecte. Langages, 61, 13-38. https://doi.org/10.3406/lgge.1981.1866. 
Prudent, L.-F., (1993). Pratiques langagières martiniquaises : genèse et fonctionnement d'un système créole. [Doctoral thesis] Thèse d'État, Université de Rouen Haute Normandie.

Prudent, L.-F., (2005). Langue et culture créoles: création d'une discipline et construction de normes. Revue française de linguistique appliquée, 1, 103-114.

Telchid, S., (2003). Kréyòl fanm chatengn. CRDP de la Guadeloupe : Pointe-àPitre

Vallverdu, F. (1972). Ensayos sobre bilingüismo. Language in Society, 4, 124124. 


\section{Taylor RaeAnne Smith}

Sorbonos universitetas, Prancūzija; trsmith0329@gmail.com

\section{ŠVIETIMO POLITIKA IR UGDYMAS KREOLU KALBA GVADELUPÉJE}

Santrauka. Istoriškai regioninès kalbos Prancūzijoje sunkiai isitvirtina nacionaliniame lingvistiniame sąraše, o prancūzu kalbos pagrindu susidariusi kreolu kalba, kaip ir kalbos, kilusios iš Gvadelupès ir Martinikos, nèra išimtis. Nepaisant istatymu ir iniciatyvu, tokiu kaip CAPES (2002) ikūrimo, ir dvikalbystès naudos tyrimu, atliktu tokiu mokslininku kaip Poth (1997) ir Cummins (2009), publikavimo, kreolu kalbos mokymas Prancūzijos užjūrio departamentuose, pavyzdžiui Gvadelupeje, vis dar vertinamas neigiamai. Šis požiūris susiformavo dèl akademinio standartizavimo trūkumo, nepaisant patvirtintu sèkmingu rezultatu mokyme, kai kreolu kalba yra naudojama pagerinti mokiniu prancūzu kalbos metalingvistinius gebejjimus. Remiantis tekstynu, sudarytu iš oficialiu kreolu kalbos mokymo gidu, pedagoginiu gidu ir vadovèlio su regioniniu prancūzišku fraziu pratimais, skirto pradedantiesiems mokiniams, taip pat ir dvieju kreolu kalbos pamoku pradedantiesiems mokiniams Gvadelupèje stebėjimu, straipsnyje pabrèžiama, kad mokytojai dažnai gauna mišrią informacija, kaip mokyti kreolu kalbos dvikalbèse klasèse. Taip pat pastebima, kad dažnai kreolu kalba prancūzu akademineje politikoje yra suprantama kaip grèsmè mokiniu prancūzu kalbos gebėjimams Gvadelupèje. Vis dèlto šiame tyrime pradedantieji mokiniai susidūrè su daugiau sunkumu kreolu kalboje nei prancūzu.

Pagrindinès sąvokos: kreolu kalba; dvikalbystè; pedagogika; Gvadelupè; švietimas; sociolingvistika. 